\title{
Universal Humanity as Discourse of Nationalism in Garin Nugroho's Soegija (2012)
}

\author{
Fredy Nugroho Setiawan, \\ M. Andhy Nurmansyah, \\ Rizki Nufiarni, \\ Scarletina Vidyayani Eka \\ Universitas Brawijaya, \\ Veteran Street, Ketawanggede, Lowokwaru, Malang City, East Java 65145 \\ fredyns@ub.ac.id
}

Article History: Submitted on $19^{\text {th }}$ April 2021; Accepted on 25th May 2021; Published on $30^{\text {th }}$ June 2021

\begin{abstract}
This research discusses nationalism in Garin Nugroho's Soegija, a biopic that premiered in 2012. The film is chosen because it presents Soegijapranata, an intellectual who is not from dominant nationalist groups during the era of the independence movement; he is neither a prominent military figure nor a figure from the largest religious group in Indonesia. This film is analyzed to investigate its position in ideological contestations emerging after the Reformation, particularly after the 2000s. Seymour Chatman's postulates regarding story and discourse in the narrative structure of fiction and film (1978) is used as a theoretical framework for this research. The results show that discourse of nationalism is presented in the narrative structure of the film in the form of arguing the idea of universal humanity in Indonesia as a nation. This effort is portrayed by the main character's intellectual struggles against shallow primordialism that influences Indonesian people's perspectives during independence movement era and foreign people's point of view, the colonizers, which are represented by subversive actions of the Dutch and Japanese in Indonesia. The values of universal humanity that have been adopted into the spirit of nationalism are stated through the main characters' statements and actions. It can be concluded that the concept of nationalism in Indonesia was born from a long struggle against oppression and injustice. This concept has become a dominant ideology that remains relevant, as implied in Soegija.
\end{abstract}

Keywords: universal humanity, discourse, nationalism, Soegija

Universal Humanity as Discourse of:... 


\section{INTRODUCTION}

Film is unique because it provides an overwhelming sense of reality it can convey (Boggs \& Petrie, 2008). This verisimilitude aspect enables a film to effectively and efficiently deliver discursive messages from its makers to the audience. This is why we choose a film as the object of the study. The film analyzed in this study is Garin Nugroho's Soegija which was released in 2012. Soegija is one of several biopics portraying prominent national figures who contribute to Indonesian independence. This film, for us, is interesting to study because of the background of the chosen main character, Soegija. $\mathrm{He}$ is not from dominant nationalist groups fighting for Indonesian independence who often become inspirations of historical war films. That is to say, and he is not a military warrior who confronts the colonizers in a battlefield. In addition, he is not a Muslim intellectual who belongs to the largest religious group in Indonesia. Therefore, this film offers "an alternative figure" among mainstream biopics.

Soegija is scrutinized to reveal its roles in articulating discourse through its narrative in the context of ideological contestations occurring after the Reformation era, especially after the 2000s when biopics flooded Indonesian cinema as if there was an emerging trend revitalizing the spirit of nationalism. Therefore, the research question is: how is the discourse of nationalism articulated in the film? As a start, we refer to two previous studies about the same film to identify a research gap so that this study can offer a new perspective. These previous studies are a literature review/ "state of the art" for our study since they were conducted recently (both in 2020). The first previous study is Pinontoan's (Pinontoan, 2020) who analyzes patriotism in Soegija using semiotic perspectives. The next previous study is done by Kartika, Prihatini, Hastanto, and Dharsono (Kartika et al., 2020) who analyze political affirmation and identity represented in the film using a deconstructive approach. Those studies reveal implied messages about patriotism, politics, and identity by scrutinizing "the texts" in the film. This study tries to provide an additional perspective that has not been discussed in the previous studies by inviting the readers to examine the film's narrative expressions to understand how nationalism is presented and how it is ideologically intended to be understood.

Textually, the similarity between novels and films lies in their position as narrative texts. According to McFarlane, "what novels and films most strikingly have in common is the potential and propensity for narrative" (McFarlane, 1996). Therefore, a film can be treated like a novel in its position as a narrative and can be analyzed by employing the approaches used to analyze written literary works. This is why Chatman's narrative theory explained in his book, Story and Discourse: Narrative Structure in Fiction and Film (1978) is used as a theoretical framework to analyze Soegija.

Universal Humanity as Discourse of:... 
Soegija tells the life story of Soegijapranata or Soegija, the film's titular protagonist, which is portrayed as a religious, nationalist, and anti-colonial figure. Soegija's resistance to colonialism and his determination to instill the spirit of nationalism in his fellow Catholics and people around him is shown in the form of intellectual struggles. He does not fight physically against the colonizers. However, He utilizes his thoughts and diplomatic position as the highest Catholic Church leader in Semarang to support the movement for Indonesian independence and help people in need, those who become victims of the independence war. Throughout the film, he is depicted as a leader who shares his critical perspectives with other figures and his followers who then agree with him and support his visions on overcoming social problems arising from the war. In addition, he makes his church a shelter for refugees and war victims provides food and medical assistance and goes into the field to interact with local communities who are frantic due to the war.

Soegija's thoughts in response to the Indonesian independence struggle is an important point to analyze. In this case, Soegija as a character becomes a medium for articulating discourse of nationalism conveyed by the filmmakers to the audience. The discourse can be traced from the ideological aspect represented by the main character's ideas which then drive his actions and influence the film's story.

\section{METHOD}

This is a qualitative-interpretive study. Qualitative means this study employs qualitative premises in data gathering by using document review method to scrutinize narrative aspects in the film and present data analysis. Interpretive refers to the way the object of the study is analyzed based on Chatman's theory, which can be summarized in Graphic 1 as follows.

Graphic 1:

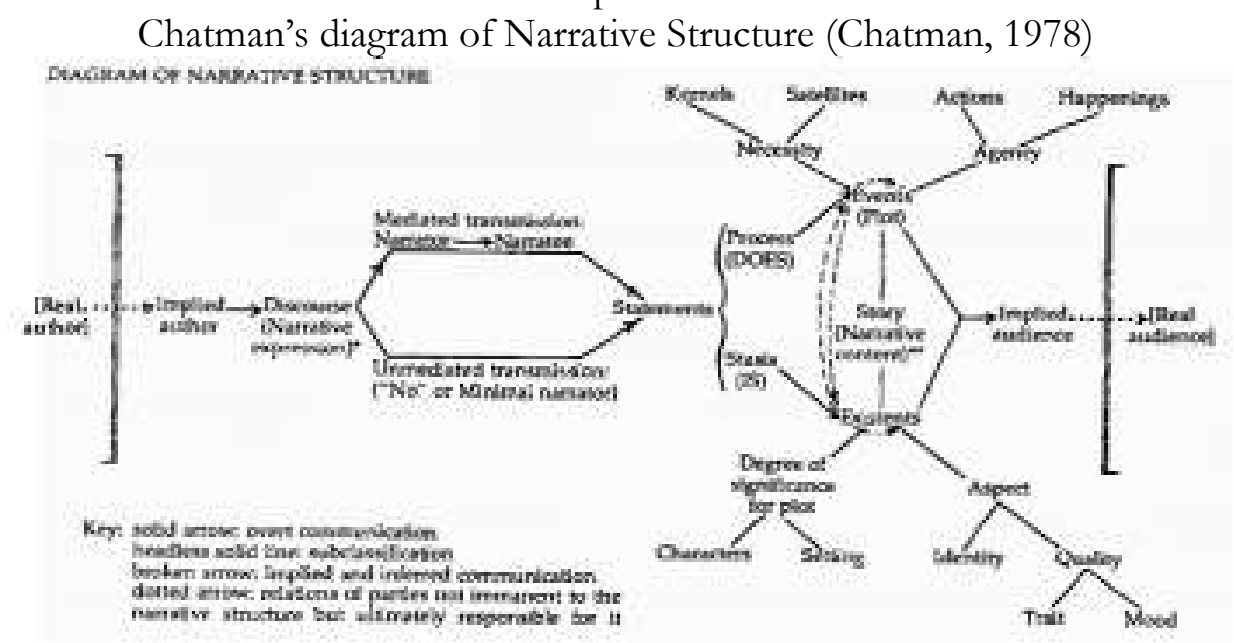

Universal Humanity as Discourse of:... 
In detail, the research steps can be explained as follows. The first step is data collection. In this step, we watched the film several times to understand its narrative aspects. Our focus was directed to the main character's talks, thoughts, actions, and interactions with other characters driven by his view about nationalism. Then, we gathered the data by referring to Chatman's premises about events and existents that constructed the film's narrative content. The data, in this case, are in the forms of selected scenes and monologues or dialogues.

The second step is categorizing or clustering the data. We categorized the identified data following its significance in shaping the film's story. At this point, we clustered the data under two categories, namely narrative element and visual element. The narrative element contains Soegija's lines of interior monologues and dialogues with other characters. Visual element showed the scenes when the monologues above and dialogues happened.

The third step is analysis and interpretation. We analyzed the categorized narrative and visual elements by employing Chatman's theory. We also used some additional references about nationalism, humanity, and film studies to support the analysis. The result of the analysis was an interpretation of nationalism in its discursive context. This step was then followed by formulating conclusions. It was where we clarified our findings and stated our final arguments, to sum up the discussion.

\section{FINDINGS AND DISCUSSION}

A statement is ideological if it is observed in its discursive context. It can be judged by who says the statement, to whom the statement is addressed, when the statement is made, and for what purpose the statement is conveyed. The ideological aspect in Soegija can be observed through the main character's statements related to issues of humanity and nationality. The statements in question here are Soegija's statements containing his views toward the situation during the Indonesian independence struggle, which in the film is realized using voice over technique. This technique is usually used to represent a character's inner monologue in a film (Pillai, 2015). In this case, the inner monologue is voiced by Soegija and appears along with the scene when he is writing a journal. In Chatman's term this is called interior monologue in the cinema, where "the voice over is identifiable as the character's, whose lips do not move" (Chatman, 1978).

Soegija views and thoughts about humanity and nationality are ideological due to several factors. The first factor is Soegija is a character in a film and film, as media, articulates ideas about how to view and understand reality. It offers a perspective on various things including, for example: how to view certain ethnic and cultural groups, women, leaders, or society through messages conveyed to the public, the path or decision taken by certain characters, the way certain characters pursue and maintain power. (Pawito, 
2014). Thus, perspectives are manifested in Soegija through his statements, attitudes, and actions, which can be listened to and witnessed by the audience. Following Chatman's premise, Soegija serves as a materialization of ideas of an implied author; an author who establishes the norms of the film's narrative and might not be a single real author in the ordinary sense (Chatman, 1978). In other words, it might represent Garin Nugroho's ideas as the director and a group of people who are involved and have control in the production of the film.

The second factor is related to the production of Soegija in 2012, which tries to portray the situations of the Indonesian independence movement that occurred in the 1940s. The decades' span between events depicted in the film and contemporary moments of its production indicate an attempt to present the "past" in the "present". Director's efforts to show historical moments of independence struggle many years ago to the millennial viewers has bridged a bond between then and now. At this point Soegija, in addition to being a biopic, serves as a historical film. This is following Jonathan Stubbs' argument in Historical Film: A Critical Introduction as follows.

Historical cinema as films...engage with history or which in some way construct a relationship to the past....these relationships to the past are created not only by the films themselves but also by cultural contexts in which they operate and the discourses that they generate (Stubbs, 2009).

The link between the past and the present also involves cultural factors in which a film is produced. This is to provide an understanding impact on the targeted audience. Thus, a film can portray events in the past but, in reality, is made and published in the present and aimed at present viewers. Historical facts are consequently not delivered without considering the zeitgeist, the existing spirit shown by the happening ideas and beliefs of a particular period when the film is released to the public. This also applies to Soegija.

In Soegija, the ideological values which drive the main character's actions can be seen in Table 1 below. The table shows the scenes (visually) when the main character writes a journal to express his thoughts and feelings. What he is writing is articulated by the character's voice-over (narratively) so the audience knows the contents of his writings at that very moment. Each scene serves either to initiate or conclude some "acts" comprising major events in the film. These scenes also signify their functions as either curtain raisers or closure of those acts. Therefore, Soegija's narrated thoughts have been the main ideas of what those acts are all about, consisting of a series of scenes constructing the film's plot. 
Table 1:

Narrative and Visual Elements of Soegija's Voice Over

Narrative element (voice over)
1. Soegija: "Kemanusian itu satu, bangsa
manusia itu satu, kendati berbeda
merupakan satu keluarga besar."(Soegija,
2012: 00:00:36-00:00:48)
(Soegija: "Humanity is one, human
race is one, even though (we are)
different, (we are) one big family.")

2. Soegija: "Apa artinya terlabir sebagai
bangsa yang merdeka jika gagal untuk
mendidik diri sendiri?"(Soegija, 2012:
00:44:43-00:44:55)
(Soegija: "What does it mean to be
born as an independent nation if we
fail to educate ourselves?")

3. Soegija: "Menggalang cinta kasih dan
keadilan belumlah cukup untuk
memelihara kedamaian diantara kita.
Disamping itu kita harus siap bertempur
dengan lemah lembut untuk
mempertahankan kemerdekaan dan peri
kemanusiaan. Sebab dalam masyarakat
kita pun terdapat juga fanatisme,
fatalisme, absolutisme, chawinisme, dan,
last but not least, egoisme." (Soegija, 2012:
01:27:56-01:28:30)
(Soegija: "Raising love and justice is
not enough to maintain peace
between us. Besides, we must be
ready to fight gently to defend our
independence and humanity.
Because in our society there is also
fanaticism, fatalism, absolutism,
chauvinism, and, last but not least,
egoism.")

Universal Humanity as Discourse of:... 


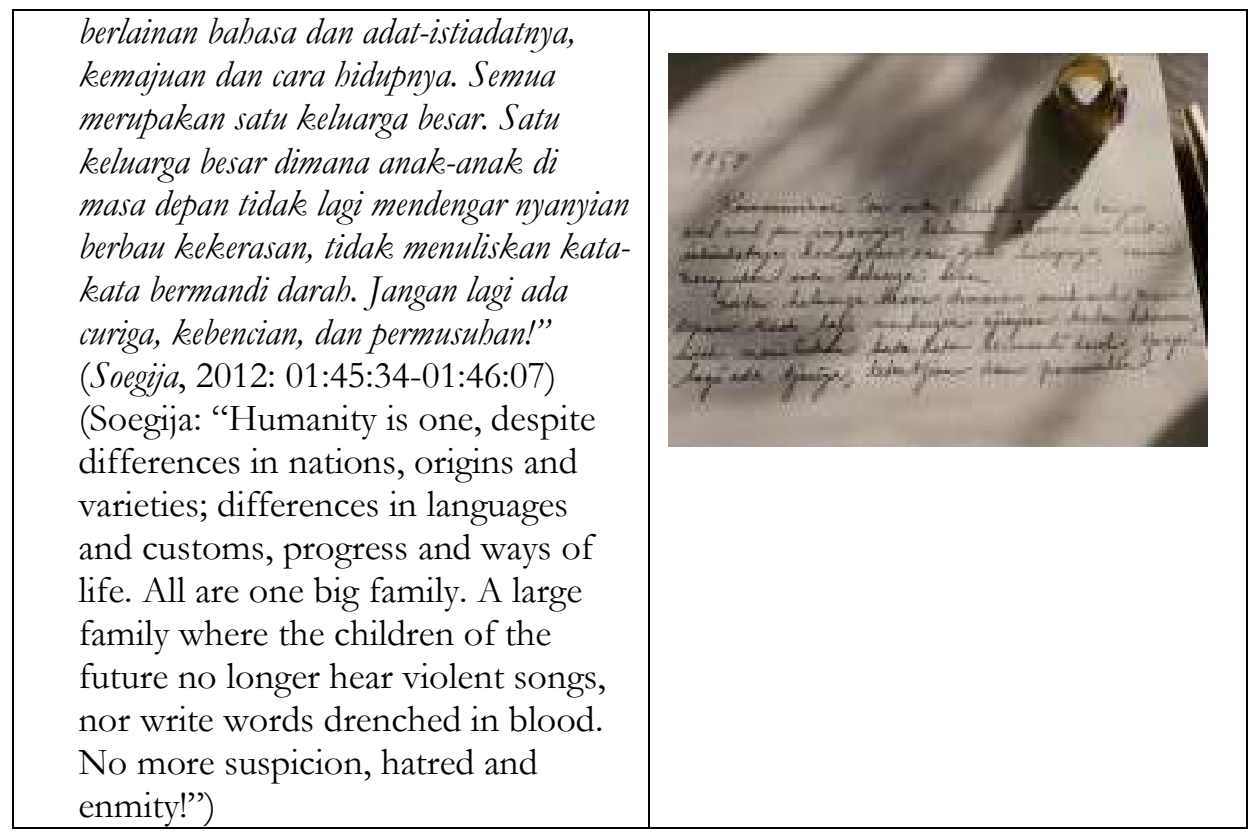

Narratively, Table 1 contains Soegija's four ideological statements expressed in interior monologues. Those statements appear in major scenes, which constitute as the kernels ${ }^{1}$ of the film. Statement no.1 appears in the early seconds of the film to introduce the scenes showing: social problems in society during the Dutch colonial era; the arrival of the Japanese and their oppression; Soegija's struggle against the colonizers and his efforts to help people in need; and the declaration of Indonesian independence. Statement no.2 precedes the scenes showing: chaos in society due to people's unreadiness for independence and they are being uneducated; the Dutch attempt to colonize Indonesia again; and Soegija's diplomatic efforts to defend Indonesia's independence. Statement no.3 initiates the scenes showing: Soegija and people's struggle to defend independence in their ways and the end of the struggle marked by the Dutch recognition of Indonesian sovereignty. Statement no. 4 is shown at the last minute of the film, which becomes a closing scene of the story, that is when Soegija is writing his journal in his chamber. In this case, Soegija's articulated ideas foreshadow the events that follow, which are not only related to his actions solely. The realization of those ideas is reflected in a series of scenes that show his interactions with other characters and scenes portraying interactions between other characters who are completely unrelated to him.

${ }^{1}$ In Chatman's term, "Kernels are narrative moments that give rise to cruxes in the direction taken by events" (Chatman, 1978). So, they are important moments or major events that create the narrative logic.

Universal Humanity as Discourse of:... 
Visually, Table 1 shows four screenshots taken from four different scenes. The screenshots depict Soegija's handwriting as he is expressing his feelings and thoughts. The screenshots are taken using the Close-Up technique which is consistently used during each interior monologue. This technique is a framing technique used to frame objects to isolate them (Villarejo, 2007). This employs the so-called subjective camera technique in which the director 'identify our vision with the character's, and positioning is camera's lens not only alongside the character, but inside, literally behind his eyes" (Chatman, 1978). Therefore, viewers are allowed to focus on seeing Soegija's writing, confirming the suitability between Soegija's writing and words at the same time. The explanation above epitomizes what Chatman calls as the chain of events (actions and happenings) and existents (characters and settings).

The views on humanity and nationality represented by Soegija comprise several things. Firstly, the belief that humanity is one and nationality is one (see: Table 1, Narrative elements no.1 and 4) expressed at the beginning and the end of the film. It implies a consistency between the opening and closing messages as if there is a match between the main idea and the conclusion. Therefore, the belief that humanity is one and nationality is an important message implied by the film. Various characters in various settings, as the existents, and interactions and conflicts among them, as the events, are manifestations of one humanity and one nation and their dynamics. Secondly, the belief that being educated in the independence era is important (see: Table 1, Narrative element no.2) which is shown in several incidents; for example, in a scene where several young Indonesian combatants sporadically attack Japanese troops without thinking and proper planning, resulting in many casualties.

Another example is in a scene where Soegija explains to the press about the chaos (robbery, looting, and scarcity of basic needs) occurring in a period of power transition that makes people suffer. This shows that opportunistic and radical actions are counterproductive to the efforts to resolve social problems post-declaration of independence. Lastly, the belief that defending freedom and humanity must be done in a pacifist, not anarchist way (see: Table 1, Narrative element no.3) supports the previous point. This reinforces the principle upheld by Soegija, that independence should be filled with mutual love to ward off shallow-minded thoughts based on differences in ethnicity, races, countries, and interests that cause disputes. This is seen as a solution for physical and mental suffering of people involved in the war, both friends and foes, as shown in several scenes in the film. 
Humanity and nationality as having been explained, refer to the ideology of universal humanity. The so-called universal humanity brings the spirit of universality of human values across cultures, religions, and countries. That is to say, all dimensions of human existence are seen as a whole regardless of any differences.

This humanism is universal.... comprising both universality (universal, general, altogether) as well as wholeness (entire, at all, whole, all inclusive). As such, it allows us to take into harmonious account present and deceased members of other nations, cultures, and religions.... this humanism also refers to the wholeness dimension, which incorporates all dimensions of human existence into a new whole, therefore integrating material, bodily, religious, spiritual, individual, social, and all other levels of human existence into a new unity (Svetelj, 2014).

Based on Svetelj's argument, it can be said that humanism that applies to all people in the world is a form of honoring multiculturalism, in which various cultures are recognized and respected equally (Taylor \& Gutmann, 1994). The attitude of respecting diversity is fundamental, in which each person can hold on to their identity and culture while welcoming other people and other cultures in a dialogical relationship. Therefore, the foundation of human values is not from one characteristic of culture, religion, or nation but the principle of equality as fellow human beings. The dialectic among people across political, social, and cultural backgrounds is constructive to achieve the harmony of life.

Humanity that every nation, including Indonesia should uphold, is highlighted as a manifestation of universal humanity values believed by the main character, Soegija. The relevance of upholding humanity with the momentum of the film which premiered in 2012 is as an emphasizes that the enforcement and application of humanity is a national mandate for Indonesians, which was initiated in the era of the independence movement and remained to be relevant to refer to, even until the time the film was released. This discourse maintains the continuity of the dominant ideology of nationalism, which in this post-Reformation era has been challenged by opposing ideologies. Through the film, one of the opposing ideologies of universal humanity is represented as shallow primordialism that triggers fanaticism, fatalism, absolutism, chauvinism, and egoism (see: Table 1, Narrative element no.3). Primordialism is a perspective that believes that ethnic ties are something natural and that identity is given from an early age, for example race (based on physical characteristics and name), language, 
belief or religion, traditions and customs, state, and everything that is in one's first environment (Llobera, 1999). Primordial sentiments resulted in negative impacts on the spirit of unity in diversity. Disunity arises because of the attitude of glorifying one's own identity, which can lead to disintegration.

Soegija has joined with other films promoting nationalism that has returned to prominence since the 2000s, after a similar theme was carried out by films released around the middle of the last century which aimed to strengthen the newly achieved independence while anticipating the threat disintegration (Heryanto, 2018). Through the imagery of the main character's ideas, the implied author shows that there is an effort to revive the spirit of nationalism, especially regarding humanitarian issues. Furthermore, a historical perspective in this film is needed because many Indonesians have experienced the so-called historical amnesia over the past few decades (Heryanto, 2018). Therefore, the making of this film can also be interpreted to prevent Indonesians from amnesia in the history of independence. Furthermore, the fact that this film was released in 2012 has provided an opportunity for younger generations who do not experience the era of independence struggle to understand nationalism, which is more than just a matter of taking up arms against colonizers and invaders.

A discourse of nationalism that has been described is further put into practice in the forms of togetherness and belief inequality, as shown by several events that involve Soegija as an alpha character. Togetherness becomes an articulation of the interests of becoming one nation and one family (see: Table 1, Narrative elements 1 and 3). This, for example, is shown in one of the scenes where Soegija is giving a speech to the church congregation. After some scenes showing the proclamation of Indonesian independence and the Dutch military aggression, this scene shows that Indonesia's economic, social, and political conditions were still unstable at that moment.

Table 2:

Soegija's Speech Before the Church Congregation

\begin{tabular}{|l|l|}
\hline \multicolumn{1}{|c|}{ Narrative element } & Visual element \\
\hline Soegija: "Lebih mudah mengelola bangsa & \\
yang seragam, dari pada mengelola bangsa & \\
yang beraneka ragam suku dan adat & \\
istiadatnya. Tetapi, dengan cara menghormati & \\
satu sama lain, kita akan bisa menjadi & \\
bangsa yang bersatu menuju keadaan yang & \\
\hline
\end{tabular}

Universal Humanity as Discourse of:... 


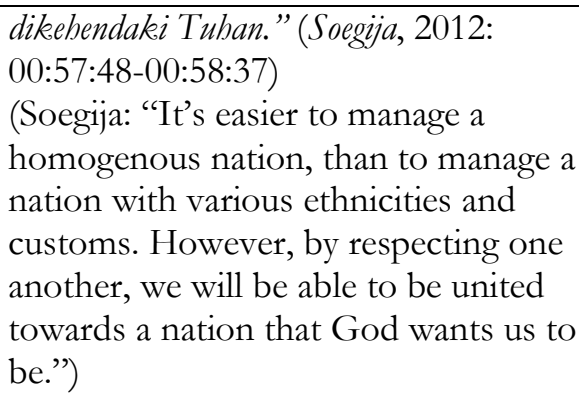

Table 2 shows Soegija's speech on national diversity and how to manage it by respecting others. The goal is unity as a nation that God blesses. The scene is taken using the Long Shot technique, which shows many people inside a church, where Soegija is standing in front of people who are sitting, watching, and listening to him. Even though the people on the scene look small, they (as object taken) (Villarejo, 2007). This presentation implies discursive action about the importance of togetherness as a nation. Soegija, as a Catholic church leader, represents authority who has the power to instill religious dogma (which on this occasion is conveyed within the framework of putting forth the issue of nationalism). Like other religious institutions, the church is an extension of the state's hand in spreading the values of nationalism; and one of the basic essences of nationalism is to prioritize common interests over personal and group interests (Kusumawardani \& Faturochman, 2004). Therefore, the function of Soegija and the church he leads in maintaining the status quo from the dominant perspective is confirmed, namely togetherness within the frame of nationalism. Soegija's role and the words he has spoken represent the nation's interest in maintaining its integrity through religious forums. In a dominant perspective, religious forums become a medium for fostering a sense of compassion and tolerance among people instead of serving minority interests that aim to glorify certain groups.

The church congregation as shown in Table 2 represents the intended stance of the implied reader ${ }^{2}$. The people in the church are taught how to make the most of their freedom by living together in harmony regardless of their ethnicities and customs. The urgency of proposing this idea is that even though they all have the same nationality, they cannot know each other personally. Instead, they are united by a mental image of nationality, as fellow people in a group can be identified together communally (Anderson, 2006). Therefore, instilling a concept of togetherness as one nation in the minds of

${ }^{2}$ The implied reader refers to the audience presupposed by the narrtive (Chatman, 1978).

Universal Humanity as Discourse of:...

Fredy Nugroho Setiawan, M. Andhy Nurmansyah, Rizki Nufiarni, Scarletina Vidyayani Eka DOI: https://doi.org/10.26714/lensa.11.1.2021.80-95 
every people is crucial to ensure national integration. This is what the filmmakers, or the implied author, try to promote through the actions of Soegija, who actively spreads out the values of nationalism in his capacity as a church leader.

In addition to the act of togetherness, belief in equality is described as another realization of nationalism values. Equality is one of the pillars of nationalism which is psychologically able to provide hope for marginalized groups of people to get equal rights and obligations. Thus, psychological motivation plays an important role in developing nationalism (Kusumawardani \& Faturochman, 2004). Thus, Soegija's perspectives, speeches, and actions in responding to other characters provide a discursive context for disseminating nationalism values. This, for example, can be shown in Table 3 as follows.

Table 3:

Sogija's Talks with Lingling about Equality

\begin{tabular}{|l|l|}
\hline \multicolumn{1}{|c|}{ Unsur Naratif } & Unsur Visual \\
\hline Lingling: "Kok setiap saat keluarga kami & \\
yang dijarah? Engkong selalu cerita tentang itu. & \\
Mama dan papa selalu bertengkar soal perlunya & \\
pagar besi yang tinggi. Apa salah keluarga & \\
kami? Ataukah karena kami Tionghoa, kami & \\
harus mengalami ini setiap waktu? Kami tidak & \\
pernah tahu." & \\
Soegija: "Lingling, tidak ada orang yang dapat & \\
merencanakan kita lahir sebagai orang & \\
Tionghoa. Orang Jawa, Orang Belanda, Orang & \\
Bali. Kamu nanti akan sekolah hukum? Nanti & \\
kamu akan ngerti, bahwa kita bisa & \\
merencanakan sebuah negara yang & \\
melindungimu, melindungi keluargamu. Negara & \\
yang bisa melindungi keselamatan setiap & \\
warganya. Kita bisa memilih pemimpin yang & \\
menjamin warganya untuk hidup dengan penuh & \\
cinta kasih dan tanpa permusuban." (Soegija, & \\
2012: 01:05:04-01:06:54) & \\
(Lingling: "Why is our family looted & \\
every time? Grandpa always told me & \\
about it. Mommy and daddy always argue & \\
about the need for a high iron fence. & \\
What's our family's fault? Or is it because & \\
we are Chinese, that we have to & \\
experience this all the time? We never & \\
know." & \\
\hline
\end{tabular}




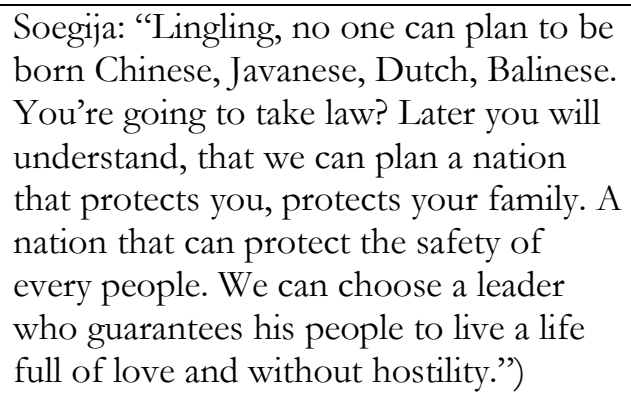

The quotation above is an excerpt from a dialogue between Soegija and Lingling. Their dialogue implies an issue regarding the need for a nation to ensure the fulfillment of its people's basic rights without exception, which is about people's safety. For this reason, the nation must have a nationalist leader, so that an underprivileged ethnic group does not need to build a high iron fence because of fear of other groups. The scene, taken using the Long Shot technique, shows two figures with a sandy and wavy beach background. The communication between the two characters contains a contemplative message about cross-ethnic equality issues. Soegija's aspiration, which is said to Lingling, a small child of Chinese descent who is still innocent, about a nation that can protect and guarantee its people to live in harmony without hostility is an articulation of national education upholds humanity based on equal rights for everyone. The depiction of Lingling as a Chinese descent who questions the injustice that happened to her family is an issue that is still relevant today. By the implied author, Lingling is a guarantee ${ }^{3}$ portrayed as the voice of a minority group that experiences discrimination in Indonesia. Various acts of discrimination against minority groups have resulted in crimes against humanity and violations of human rights that should be guaranteed by the constitution (Fadhli, 2014; Risdianto, 2017). In other words, Lingling's words represent a latent problem in Indonesia regarding the implementation of the so-called equal rights, especially for Chinese descendants, while Soegija's words are an ideal position that the nation in solving this problem should take. All in all, togetherness and belief in equality are forms of discursive actions as an embodiment of universal humanism. This discursive relationship can be explained in Graphic 2 as follows.

\footnotetext{
${ }^{3}$ A naratee is a character in the world of work serving as a device by which the implied author informs the real reader how to perform as implied reader (Chatman, 1978:150).
}

Universal Humanity as Discourse of:... 
Graphic 2:

Discursive Relationship in Soegija

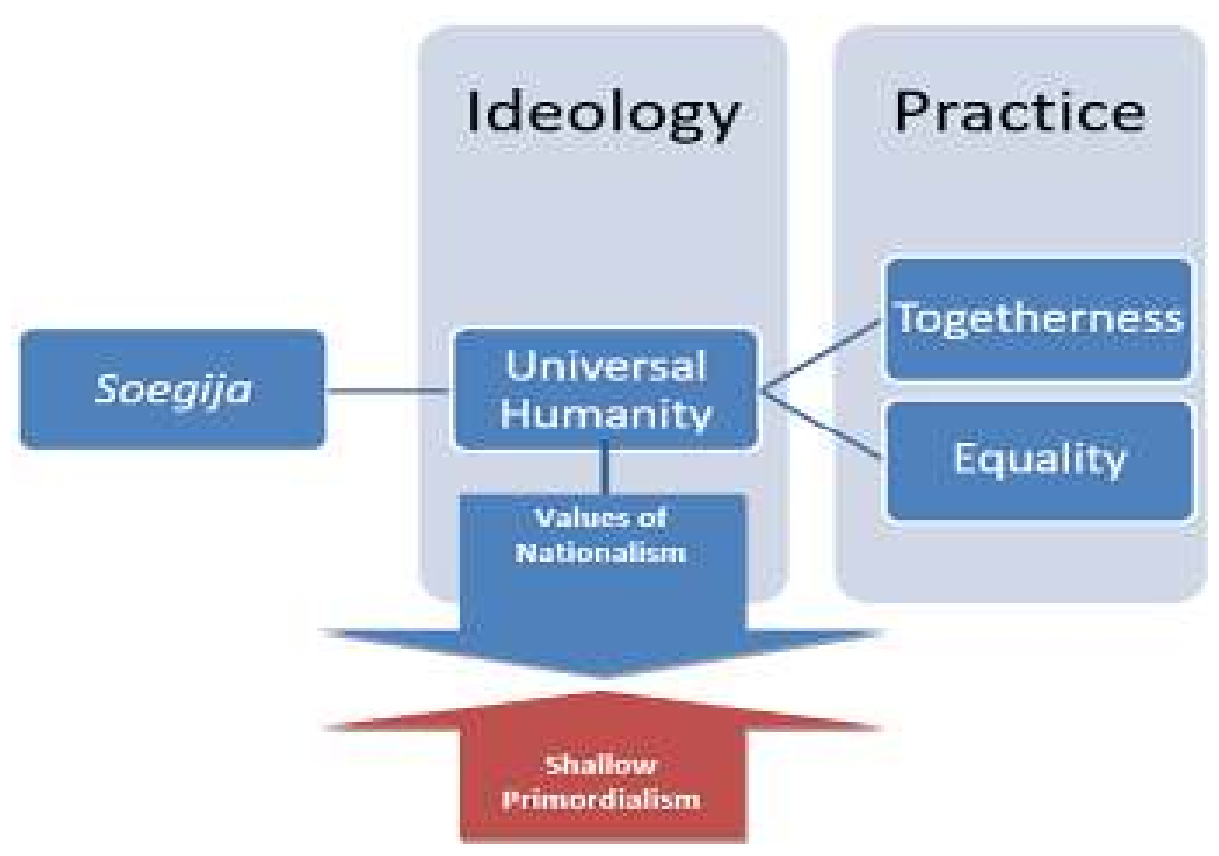

\section{CONCLUSION}

A discourse of nationalism in Soegija (2012) is presented to uphold nationalism as a manifestation of universal humanity. The effort is based on an intellectual struggle against shallow primordialism that influenced both Indonesians and the colonizers (the Dutch and Japanese) back then in the era of the independence movement. The presentation of Soegija as the main character and the narrative about and around him confirm the implied author's intention in delivering values of nationalism to the implied reader, the role which is expected to be played by the real reader(s) - the viewers - of Soegija. Universal humanity implied in discursive expressions of the main character, who structurally performs as an existent in the story, leads to a series of actions and happenings that construct the film's narrative. Ideologically, it serves as a tool to put forth the concept of Indonesian nationalism, which remains relevant. This further implies that the presented nationalism values result from the intellectual process undergone by national figures and a long struggle across generations and ages against all forms of ideological threats and oppression and injustice. 


\section{ACKNOWLEDGEMENT}

Our gratitude goes to the Advisory Board of Research and Community Service, Faculty of Cultural Studies, Universitas Brawijaya, supporting our research. This article is part of an unpublished research report that we did last year.

\section{REFERENCES}

Anderson, B. (2006). Imagined Communities: Reflections on the Origin and Spread of Nationalism (Revised Edition). Verso.

Boggs, J. M., \& Petrie, D. W. (2008). The Art of Watching Films. McGraw Hill.

Chatman, S. (1978). Story and Discourse: Narrative Structure in Fiction and Film. Cornell University Press. https://doi.org/10.1075/is.8.2.02you

Fadhli, Y. Z. (2014). Kedudukan Kelompok minoritas dalam Perspektif HAM dan Perlindungan Hukumnya di Indonesia. Jurnal Konstitusi, 11(2), 352-370.

Heryanto, A. (2018). Identitas dan Kenikmatan: Politik Budaya Layar Indonesia. Kepustakaan Populer Gramedia.

Kartika, B. A., Prihatini, N. S., Hastanto, S., \& Dharsono, D. (2020). Soegija Biopic Film, Political Afirmation, and Political Identity:

Deconstruction of Indonesian Historiography. Capture : Jurnal Seni Media Rekam, 12(1), 28-47. https://doi.org/10.33153/capture.v12i1.3111

Kusumawardani, A., \& Faturochman. (2004). Nasionalisme. Buletin Psikologi, 12(2), 61-72.

Llobera, J. R. (1999). Recent Theories of Nationalism.

McFarlane, B. (1996). Novel to Film: An Introduction to the Theory of Adaptation. Clarendon Press.

Pawito. (2014). Meneliti Ideologi Media : Catatan Singkat. Profetik, 7(1), 514.

Pillai, S. E. (2015). The Texture of Interiority: Voiceover and Visuals. Studies in Visual Arts and Communication: An International Journal, 2(1), 112.

Pinontoan, N. A. (2020). Representasi Patriotisme Pada Film Soegija (Analisis Semiotika John Fiske). Avant Garde, 8(2), 191-206. https://doi.org/10.36080/ag.v8i2.1226

Risdianto, D. (2017). Perlindungan Terhadap Kelompok Minoritas Di Indonesia Dalam Mewujudkan Keadilan Dan Persamaan Di Hadapan Hukum. Jurnal Rechts Vinding: Media Pembinaan Hukum Nasional, 6(1), 125-142. https://doi.org/10.33331/rechtsvinding.v6i1.120 
Stubbs, J. (2009). Historical Film: A Critical Introduction. Bloomsbury. https://doi.org/10.5040/9781501351044

Svetelj, T. (2014). Universal Humanism - A Globalization Context is the Classroom of Unheard Options how to Become More Human. The Person and the Challenges. The Journal of Theology, Education, Canon Law and Social Studies Inspired by Pope John Paul II, 4(1), 23-36. https://doi.org/10.15633/pch.44

Taylor, C., \& Gutmann, A. (Ed. . (1994). Multiculturalism. Princeton University Press.

Villarejo, A. (2007). Film Studies: the Basics. Routledge. https://doi.org/10.2307/25557395 